\title{
The policy of the People's Republic of China towards Central and Eastern Europe in 2012-2020
}

\section{The policy of the People's Republic of China towards Central and Eastern Europe in 2012-2020}

\section{Abstract}

In the second decade of the $21^{\text {st }}$ century, the Middle Kingdom, which had huge financial surpluses, became the world's largest exporter of money capital, which meant that investment policy became the main element of China's foreign policy. In the case of Central and Eastern Europe, the 16+1 (17+1) format, containing both investment policy and soft power elements, has become the basic tool of the general policy of Middle Kingdom. This article aims to define the basic principles of China's policy towards Central and Eastern Europe. For this purpose, the following general hypothesis was formulated: Chinese policy in Central and Eastern Europe consists of presenting the countries of this region with initiatives that do not go beyond the sphere of declarations and serve as a bargaining chip in relations with Germany, the country with the greatest potential in the European Union.

The general hypothesis gives rise to detailed hypotheses that were verified in individual parts of the article with the use of the comparative method. The reasons most often mentioned in the literature on the subject, such as economic, cultural, social, and political differentiation of Central and Eastern European countries, legal barriers resulting from EU legislation, insufficient recognition of the region's needs by the Chinese side and asymmetry of expectations of both parties, undoubtedly largely contribute to the lack of effective Sino-CEE cooperation. However, they cannot be considered decisive because 
similar problems occur wherever Chinese companies appear. However, in many regions of the world, despite these obstacles, mutual economic relations are more dynamic than in CEE. The reasons why the potential of the $16+1(17+1)$ format has not been properly used can be found primarily in the context of German-Chinese relations.

Keywords: China, CEE, Germany, 16+1, China-CEE, China-UE

\section{Политика Китайской Народной Республики в отношении Центральной и Восточной Европы в 2012-2020 гг.}

\section{Аннотачия}

Во втором десятилетии XXI века Китай, имевший огромные финансовые излишки, стал крупнейшим в мире экспортером денежного капитала, а это означало, что инвестиционная политика стала важным элементом внешней политики Китая. В случае Центральной и Восточной Европы формат 16+1 (17+1), содержавший компонент инвестиционной политики и элементы мягкой силы, стал основным инструментом общей политики Китая в отношении Центральной и Восточной Европы. Для этого была сформулирована следующая общая гипотеза: суть политики Китая в Центральной и Восточной Европе заключалась в том, чтобы представить странам этого региона инициативы, которые не выходили за рамки деклараций и являлись разменной монетой в отношениях с Германией - страной с наибольшим потенциалом в Европейском Союзе.

Общая гипотеза порождает детальные гипотезы, которые в отдельных частях статьи проверялись сравнительным методом. Причины, которые чаще всего упоминаются в литературе, такие как экономическая, культурная, социальная и политическая дифференциация стран Центральной и Восточной Европы, правовые барьеры, возникающие в результате законодательства Европейского Союза, недостаточное признание потребностей региона китайской стороной и асимметрия ожиданий с обеих сторон, несомненно, в значительной степени способствуют отсутствию эффективного сотрудничества. Однако, несмотря на это, их нельзя считать решающими, поскольку подобные проблемы возникают везде, где появляются китайские компании. Во многих регионах мира, несмотря на эти препятствия, взаимные экономические отношения более динамичны, чем в Центральной и Восточной Европе. Причины неэффективного использования потенциала формата 16+1 (17+1) можно найти прежде всего в контексте германокитайских отношений.

Ключевье слова: Китай, Центральная и Восточная Европа, Германия, 16+1, Китай - ЦВЕ, Китай - ЕС 


\section{Introduction}

The article attempts to show the causes and effects of the PRC's involve1 ment in Central and Eastern Europe. In the second decade of the $21^{\text {st }}$ century, the Middle Kingdom, which had huge financial surpluses, became the world's largest exporter of money capital, which meant that investment policy became the main element of China's foreign policy. In the case of Central and Eastern Europe, the 16+1 (17+1) format, containing both investment policy and soft power elements, has become the basic tool of the general policy of the Middle Kingdom.

The article is descriptive, explanatory and, to some extent, prognostic, based on a realistic paradigm in international relations within which a geopolitical theory and the theory of the balance of power were created, defined as a policy aimed at achieving a certain state of affairs. This article aims to define the basic principles of China's policy towards Central and Eastern Europe. For this purpose, the following general hypothesis was formulated: Chinese policy in Central and Eastern Europe consists of presenting the countries of this region with initiatives that do not go beyond the sphere of declarations and serve as a bargaining chip in relations with Germany, the country with the greatest potential in the European Union.

The following detailed hypotheses follow from the general hypothesis and were verified in individual parts of the article using the comparative method:

1. Changes in Chinese policy towards Central and Eastern Europe result from the expansion of the Chinese economy caused by Deng Xiaoping's reforms.

2. The $16+1(17+1)$ format is not effective as a platform for implementing the interests of the CEE countries.

3. The reasons most often mentioned in the literature on the subject, such as economic, cultural, social, and political differentiation of Central, and Eastern European countries, legal barriers resulting from EU legislation, insufficient recognition of the region's needs by the Chinese side, and asymmetry of the expectations of both parties, undoubtedly largely contribute to the lack of effective cooperation of Sino-CEE. But they cannot be considered decisive because similar problems occur wherever Chinese companies appear. However, in 
many regions of the world, despite these obstacles, mutual economic relations are more dynamic than in CEE.

4. The reasons why the potential of the $16+1(17+1)$ format was not properly used should be sought primarily in the context of German-Chinese relations.

5. The $16+1(17+1)$ format is effective as a Chinese soft power tool.

6. An increase in Chinese infrastructure investments in Central and Eastern Europe in the foreseeable future is very unlikely.

The introduction to the verification of specific hypotheses is an attempt to answer research questions concerning the definition of Central and Eastern Europe as a region in international relations and its potential.

\section{Central and Eastern Europe as a region in international relations}

The basic research problem is to define which countries should be included in this region of Europe and based on what criteria. The concepts of Central, and Eastern Europe include: historical (Magocsi, 2005), cultural (Kundera, 1984), and geographical (Romer, 1989). The article adopts the definition of Central and Eastern Europe introduced by Oskar Halecki to describe an area that differs geographically, historically and culturally from Western Europe on the one hand, and from Russia treated as a separate continent on the other (Halecki, 1944, p. 14). This approach includes the countries located north of the Alps, in the Danube basin, and the Balkans, not only those with a predominance of the Slavic ethnos but also Finland, Hungary, Romania and Greece. The area where the countries from the $16+1(17+1)$ format proposed by Beijing are located largely coincides with Central, and Eastern Europe, distinguished by Halecki. Therefore, the article includes Latvia, Lithuania, Poland, the Czech Republic, Slovakia, Hungary, Romania, Slovenia, Croatia, Serbia, Bosnia and Herzegovina, Montenegro, Bulgaria, Macedonia, Albania, and Greece in this region.

Taking into account the above premises, the article rejects the systematization of European countries used in the analysis of relations with China by the influential German think tank MERICS, which distinguishes: Eastern Europe with Austria, Bulgaria, the Czech Republic, Hungary, Poland, Romania 
and Slovakia; Southern Europe with Croatia, Cyprus, Greece, Italy, Malta, Portugal, Slovenia and Spain and Northern Europe with Estonia, Denmark, Finland, Ireland, Latvia, Lithuania and Estonia (Hanemann, Huotari, Kratz, 2019 , p. 11). Despite certain substantive premises, such a division has limited explanatory possibilities, because in the perception of major players on the international arena: the USA, China and Russia, Central and Eastern Europe is perceived as a separate region.

Another important research question concerns the concept of 'geopolitical potential' which consists of the following elements: spatial, demographic, economic and military. The potential of Central and Eastern Europe due to its geopolitical location is much greater than it would appear from its area (27 percent of the European Union), population (22 percent) and GDP (10 percent). In his original concept of the 'Heartland', H.J. Mackinder wrote that "Who rules East Europe commands the Heartland: Who rules the Heartland commands the World-Island: Who rules the World-Island commands the World" (Mackinder, 1942, p. 150).

From the point of view of contemporary geopolitics, the Baltic-Black Sea Bridge is still perceived as one of the key elements of the global system by the largest players in the international arena. For the USA, the states of Central and Eastern Europe can effectively counterbalance the growing potentials of Germany, Russia and China, effectively hindering their integration. The region is also an outlet for US liquefied natural gas. China perceives Central and Eastern Europe as an extremely important element in building the New Silk Road (Pabisiak, 2020; Olechowski, 2020). For Germany, and the countries of the 'Old Union', it is a reservoir of cheap and qualified workforce and a sales market. Russia perceives the countries of this region as the main obstacle in relations with Germany, and therefore aims to deprive them of their political subjectivity.

\section{Sino-CEE relations until 2012}

After World War II, the CEE countries came under the domination of the Soviet Union (except Greece), and in October 1949, after the victory of the communists, the People's Republic of China was proclaimed by Mao Zedong. Until the Soviet-Chinese conflict following Stalin's death, which 
ultimately led to a split in the Eastern bloc, Beijing's policy towards the CEE countries was in line with Moscow's political line. In October 1956, Mao Zedong supported the changes in Poland to mark his influence on other communist states, thus breaking Moscow's monopoly.

In the context of relations with China at that time, Albania was a special case among the CEE countries, which after the conflict with Yugoslavia in 1948 entered into a close alliance with the Soviet Union. In 1961, the authorities in Tirana severed relations with their strategic partner, becoming a close ally of China until 1978. This was due to the warming of the hitherto hostile relations between Moscow and Belgrade. In the case of Romania, maintaining good relations with Beijing after the Sino-Soviet split was dictated by the desire to become independent from the Soviet Union. Nicolae Ceausescu did not break completely with the Eastern Bloc while trying to get closer to China, which he visited in 1971. It is significant that after this year's visit to Romania, a cult of a leader analogous to the cult of Mao Zedong was introduced.

In 1961-1978, relations with China of the CEE countries dominated by the Soviet Union were strictly subordinated to the Kremlin's political line. After Mao Zedong's died in 1976, Deng Xiaoping won the power struggle, partially liberalizing the economy, and initiating a policy aimed at ending China's isolation. There has also been a normalization of relations with Russia, and thus with the CEE countries subordinated to it. The collapse of communism in $\mathrm{CEE}$ and the political and economic transformation initially had little impact on relations with China, which, especially after the brutal suppression of the protests at Heavenly Peace Square in June 1989, were still perceived as a communist and oppressive state in which fundamental human rights are violated.

In the early 1990s, China, striving to break its political isolation, intensified diplomatic activities towards the CEE countries. Continuing his cooperation, the Chinese Prime Minister, Li Peng, visited Romania in 1994, which resulted in the development of mutual trade. In 1996, Chinese President Jiang Zemin, during his visit to Romania, signed an agreement on mutual scientific, technological, and trade cooperation. In 1997, President Emil Constantinescu signed another package of agreements in Beijing, declaring his support for China's position on Taiwan.

President Aleksander Kwasniewski made a similar declaration during his visit to China, In a joint communiqué of the Republic of Poland and 
the People's Republic of China of November 17, 1997, it was stated: "The Polish side reiterates that the Republic of Poland recognizes that there is only one China in the world and that it is the People's Republic of China, and that Taiwan is an inseparable part of the territory of China, and the Government of the People's Republic of China is the only legal government representing all of China" (Oficjalna Strona Prezydenta Rzeczypospolitej Polskiej, 2000).

The years 1989-1994 were a period of stagnation in China's relations with the CEE countries, while the years 1994-2001 can be described as a period of their revival. However, the real intensification of mutual relations took place only after December 11, 2001, when China joined the World Trade Organization after negotiations lasting over a year. This became a turning point for the expansion of the Chinese economy, which gained the opportunity to export goods on an unprecedented scale. The Chinese authorities, in line with the 'going out' strategy, encouraged enterprises to expand into international markets. Due to low production costs and cheap labor, China, which has specialized in the production of textiles and energy-consuming industrial production, has become the "factory of the world" to record a 10\% increase in GDP in the following years.

China's rapid economic development is largely the result of Deng Xiaoping's reform efforts, who, despite resigning from all official functions in the 1990s, remained the undisputed leader until he died in 1997. His protégé, political follower and successor, Jiang Zemin, brought China into the WTO. In the years 2002-2012, when Hu Jintao was the Secretary General of the Communist Party of China, numerous measures were taken to intensify trade relations with the countries of the European Union.

In 2003, China's policy towards the EU was defined as the concept of economic rapprochement (Mission of the People's Republic of China to the European Union, 2016). An example of the implementation of this strategy is the contract concluded in December 2005 by the prime ministers of the PRC - Wen Jiabao and France - Dominique de Villepin with the Airbus consortium for 10 billion euros (Avitrader, 2005). At the same time, the CEE countries, as current and future EU members, became the object of Beijing's interest, as evidenced by Wen Jiabao's visit to Poland, Hungary, and Romania in 2004. 


\section{Establishing and implementing investment goals of the $16+1(17+1)$ format}

In 2011, Middle Kingdom organized an economic forum in Budapest. A year later, Chinese Prime Minister Wen Jiabao, during his visit to Warsaw at the Central Europe-China economic forum, officially presented Sino-CEE cooperation proposals under the $16+1$ format. It was addressed to 16 countries of the former Eastern bloc: Albania, Bosnia and Herzegovina, Bulgaria, Croatia, the Czech Republic, Estonia, Hungary, Latvia, Lithuania, Macedonia, Montenegro, Poland, Romania, Serbia, Slovakia, and Slovenia, 11 of which belonged to the EU European Union and 12 to the North Atlantic Pact.

The declarative goals of the Chinese side were presented by Wen Jiabao. Speaking during the forum in Warsaw, he presented 12 steps for friendly cooperation with Central and Eastern Europe, which are to be the basis for Sino-CEE cooperation. Seven of them concern investment policy:

1. Set up a secretariat for cooperation between China and central and eastern European countries. The secretariat will be based in China's Ministry of Foreign Affairs, and charged with communication and coordination on matters related to cooperation, preparation for leaders' meetings and business forums and implementation of relevant outcomes. The 16 central and eastern European countries will, in the principle of voluntarism, each designate a counterpart department and a coordinator to take part in the work of the secretariat.

2. Establish a USD 10 billion special credit line, a certain proportion of which will be concessional loans, with a focus on cooperation projects in such areas as infrastructure, high and new technologies, and green economy. The 16 central and eastern European countries may file project application to the National Development Bank of China, Export and Import Bank of China, Industrial and Commercial Bank of China, Construction Bank of China, Bank of China or China Citic Bank.

3. Set up an investment cooperation fund between China and central and eastern European countries with the goal of raising USD 500 million in the first stage.

4. China will send trade and investment promotion missions to central and eastern European countries and take concrete steps to move 
forward bilateral economic cooperation and trade. China would like to work with the 16 central and eastern European countries to increase total two-way trade to USD 100 billion by 2015 .

5. China will, in the light of actual conditions and needs of central and eastern European countries, encourage Chinese enterprises to cooperate with relevant countries to establish one economic and technological zone in each country in the next five years. China will continue to encourage and support more Chinese enterprises to take part in the development of existing economic and technological zones in the relevant countries.

6. China stands ready to actively explore with the 16 central and eastern European countries financial cooperation such as currency swap, local currency settlement for cross-border trade, and establishment of bank branches in each other's countries, with a view to enhancing support and services for practical cooperation.

7. Establish an expert advisory committee on the construction of transportation network between China and central and eastern European countries. With the Ministry of Commerce of China as the coordinator and the 16 central and eastern European countries participating on a voluntary basis, China and the European countries will explore the building of regional highway or railway demonstration networks through joint venture, joint contracting and other means (Ministry of Foreign Affairs of the People's Republic of China, 2012)

The $16+1(17+1)$ format was the result of great hopes for both the Chinese side and the CEE countries. The very fact of the offer addressed to this group of countries indicates that the Chinese perception of Central and Eastern Europe is geopolitical in nature. The countries of this part of Europe differ in every respect: politically, religiously, socially, historically, they are one from the point of view of the Middle Kingdom.

The establishment of the $16+1(17+1)$ format is closely related to the announcement by President Xi Jinping in September 2013 at the Nazarbayev University in Astana of the project to expand the infrastructure connecting the countries of Eurasia. The New Silk Road is another version of President $\mathrm{Hu}$ Jintao's concept of "opening China to the world" through capital exports (Stokes, 2015). The goal of the Chinese side was to create a foothold in 
Central and Eastern Europe as a potential transit point for Chinese goods. It was also supposed to be a way to come into contact with the economies of Germany and other countries of the 'Old Union' - Austria, Belgium, Denmark, Finland, France, Greece, Spain, the Netherlands, Ireland, Luxembourg, Portugal, Sweden, Great Britain, Italy (Matura, 2012).

Great Expectations also appeared among the CEE countries for which the $16+1(17+1)$ format was an opportunity to finance infrastructure. Above all, it was hoped that China, with huge financial surpluses, had become the world's largest exporter of money capital. Co-financing the rail and road infrastructure in the $\mathrm{CEE}$ countries would be in the vital interest of the Middle Kingdom, as only then would it be possible to efficiently transport goods along the emerging New Silk Road to Western Europe.

China achieved its main goal, which was to increase economic exchange with the countries of 'Old Europe', primarily with Germany. The 16+1 $(17+1)$ format turned out to be an extremely effective bargaining chip in trade negotiations with the countries of the 'Old Union'. On the other hand, the expectations of the CEE countries in the area of investment have not been met. In 2014, the first of the 12 steps of Prime Minister Wen Jiabao was implemented in Warsaw: the Permanent Secretariat of 16 countries of Central and Eastern Europe and China for investments was created, which was the result of the agreement of the Polish Information and Foreign Investment Agency (PAIiIZ) and the China Investment Promotion Agency.

The appointment of the Secretariat of 16 countries of Central and Eastern Europe and China for investments was accompanied by declarations of cooperation. Deputy Prime Minister, Minister of Economy Janusz Piechociński stated that: "All countries in the region are interested in increasing the inflow of investments from China. We mainly expect those that create new jobs and entail the inflow of new technologies, increasing the innovativeness of economies". In turn, Li Dianxun, CEO of China's Investment Promotion Agency (CIPA) stated, "I hope the investment will be worth \$ 500 million in a few years" (Polska Agencja Inwestycji i Handlu S.A., 2014). In practice, it was another step after the establishment of the Permanent Secretariat at the Chinese Ministry of Foreign Affairs in 2012 on the way to bureaucratization and institutionalization of the $16+1$ format, which, however, did not have a great impact on the specific effects of cooperation between Sino-CEE. 
The second of Wen Jiabao's 12 steps, the creation of a special USD 10 billion credit line, did not meet the expected results. Until 2016, China Exim Bank and China Development Bank financed mainly energy projects in CEE countries that are not members of the European Union: Serbia, Macedonia, Bosnia, and Herzegovina, and Montenegro.

\section{Causes of inefficiency of the $16+1(17+1)$ format}

The scale of China's investments in CEE countries, amounting to around EUR 10 billion in 2000-2019, is evidenced by their comparison with investments made in Finland in the same period, amounting to EUR 12 billion.

Michał Lubina (2019) lists the following factors as the reason for this state of affairs:

1. Economic, cultural, social, and political diversification of CEE countries

2. Legal barriers resulting from $\mathrm{EU}$ legislation

3. Insufficient recognition of the region's needs by the Chinese side

4. The asymmetry of the expectations of both sides

Research conducted at the enterprise level confirms the extremely important role of the cultural factor. KPMG - a global organization of independent companies providing audit and advisory services, in the instructional brochure on relations with Chinese companies, which is published, presents data resulting from surveys (KPMG International, 2010). When asked "in which areas has your company encountered the greatest difficulties?" the following responses were given:

Generating synergies $49 \%$

Culture issues $47 \%$

Organisational designing $43 \%$

HR-related issues $43 \%$

New vision and strategy $39 \%$

Financial issues $35 \%$

Customer retention $22 \%$

Transitional product/ brand strategy $14 \%$

Other $8 \%$ 
A typical example of an unsuccessful investment as a result of the accumulation of the above problems may be the scandal with the Chinese company Covec, which failed to complete the construction of the A2 motorway section between Warsaw and Łódź for the amount of PLN 1.3 billion (Banasiak, 2015).

Turcsányi and Qiaoan (2020) point to the anti-communist resentment in the CEE countries dominated by the USSR after World War II. The perception of the Middle Kingdom as an oppressive state in which fundamental human rights are violated would be an important factor that hinders the development of Sino-CEE cooperation.

The above-mentioned factors undoubtedly largely contribute to the lack of effective economic cooperation, however, they cannot be considered decisive. Similar problems occur wherever Chinese companies appear, but in many regions of the world, despite these obstacles, mutual economic relations are more dynamic than in CEE. An example is Africa, where in 2000 the Middle Kingdom established the Sino-African Cooperation Forum (FOCAC), an organization in many respects analogous to the $16+1(17+1)$ format (Gruszczyński, 2016, p. 26-28, 63-67, 74-77).

According to the data of Johns Hopkins University School of Advanced International Studies in Washington Chinese financial institutions granted a total of USD 148 billion to African governments and companies in 2000-2018. Most of this amount was invested in the development of communication infrastructure (China Africa Research Initiative, 2019). A function similar to that of FOCAC is performed by the Community of Latin American and Caribbean States (CELAC) (Fornes, Mendes, 2018). In 2012 Wen Jiabao announced the Trusted Friends Forever policy as a result of which there was a very rapid increase in trade between China and the countries of this region. Total Chinese investment in Latin America and the Caribbean amounted to USD 130 billion between 2005 and 2019 (The Congressional Research Service, CRS, 2020).

The scale of Chinese investment in both Africa and Latin America is due to three basic factors: raw materials, cheap labor, and a market for over a billion people. The CEE countries do not have such advantages on a comparable scale, however, even the greater attractiveness of Africa and Latin America for the Middle Kingdom does not explain such a huge difference 
in investments under FOCAC, CELAC, and the 16+1 (17+1) format. More so as investing in the communication infrastructure of the CEE countries would be extremely beneficial for the Middle Kingdom due to the connection of the New Silk Road with Western Europe.

The PRC in all regions of the world bases its economic expansion on the same pattern of action. FOCAC, CELAC, and the 16+1 (17+1) format are similar even in organizational details. Therefore, the question becomes why the Chinese investment policy pursued so successfully in Africa and Latin America in CEE ended in a fiasco, contrary to official assurances of all interested parties.

\section{The ineffectiveness of the $16+1(17+1)$ format in the context of Sino-German relations}

The explanation of the reasons why the potential of the $16+1(17+1)$ format has not been properly used should be sought primarily in the context of German-Chinese relations. Beijing has become Berlin's main trading partner. Since 2000, German exports to Middle Kingdom have increased from EUR 9.5 billion to EUR 96 billion, providing employment to almost half of Germans employed in industry (Rudnicka, 2020).

In this situation, a possible increase in Chinese investments in CEE is perceived by Berlin, which has been systematically consulting with Beijing since 2010 as a threat to its interests. From the inauguration of the Belt and Road Initiative, one of the main goals of German policy has been to control relations with China through the institutions of the European Union. According to Jan Gaspers: "In light of the prevailing uncertainty about the geopolitical implications and economic sustainability of the BRI, the German government is actively trying to coordinate Europe's response to this initiative and its involvement in it through the EU, the Organization for Security and Cooperation in Europe (OSCE), or the G20" (Gaspers, 2016).

The narrative of German government factors on this issue is conducted mainly under the slogans of "preserving European unity" and warning other countries against falling into dependence on a stronger Chinese partner. As the German Foreign Minister Sigmar Gabriel stated at a meeting in 2017 
in Paris: "If we do not succeed for example in developing a single strategy towards China, then China will succeed in dividing Europe" (Poggetti, 2017).

According to his successor Heiko Massa, "If some countries believe that you can do wise business with the Chinese, they will be surprised and wake up in addiction someday" (Frankfurter Allgemeine Zeitung, 2019). The statement by the German minister of foreign affairs is interesting because in 2016 the Chinese, despite protests from the German side, successfully took over the robotics company KUKA and the KraussMaffei concern operating in the machine and defense industry (Chazan, 2016).

The functions fulfilled in Chinese politics by the $16+1(17+1)$ format have changed over time. On the one hand, the main goal of Middle Kingdom has been achieved, namely dependence on exports of the German economy. On the other hand, Berlin, both directly and through EU institutions, effectively influenced the governments of the CEE countries willing to develop economic cooperation with Beijing on their own. The pressure from Brussels and Berlin is effective because most of the exports to China from CEE countries are controlled by international companies. As they suggest Turcsányi, Matura, Fürst (2014) this is the case with 90 percent of exports from the Czech Republic, Slovakia, and Hungary to the Middle Kingdom. The exceptions among the CEE countries are the Balkan countries that are not members of the European Union: Serbia, Bosnia, and Herzegovina, Montenegro, Bulgaria, Macedonia and Albania, which received almost 70 percent of USD 15.4 billion under the $16+1(17+1)$ format invested by China (Hutt, 2020).

Some opportunities to change this situation appeared in 2015 due to the change of the government team in Poland, which is the largest CEE country. However, both President Andrzej Duda's visit to China in 2015 and Xi Jinping's visit to Warsaw in 2016 did not bring the expected results, as relations with the United States became the top priority for Polish authorities. This factor became even more important as the US-China trade war intensified.

In this situation, the Middle Kingdom after 2016 is limited only to those investments in CEE countries that do not in any way conflict with its interests in the "Old Union" countries, especially in Germany. This approach is in line with the Chinese way of conducting foreign policy, which consists of focusing on relations with the strongest partners in a given region. Therefore, it should 
be assumed that the window of opportunity for the acquisition of Chinese investments by CEE countries on a scale comparable to that of African and Latin American countries was open only in 2012-2016.

Official rhetoric depicting the achievements of the $16+1(17+1)$ format as a huge success and Beijing's political gestures seem to contradict this. China is trying to prove that its proposal for the peripheral areas of Europe is still valid. This impression was deepened by the fact that Greece joined the group of 16 CEE countries at the 2019 summit in Dubrovnik. This was closely related to the takeover of the largest Greek port in Piraeus by COSCO Shipping, but it was also perceived as an attempt to further develop cooperation with CEE countries (Koutantou, Goh, 2016).

\section{The efficiency of the $16+1(17+1)$ format as a Chinese soft power tool}

The paradox of China's policy towards CEE countries is only apparent. The fact that this policy is effective is evidenced by the statement by German minister Sigmar Gabriel about China breaking the unity of Europe and the statement by the European Commission of March 2019 describing it as "a systemic rival and economic competitor of the EU" (European Commission, 2019).

The Middle Kingdom cares about the continued existence and functioning of the $16+1(17+1)$ format without involving its resources too much, as it is a convenient bargaining chip in Beijing's negotiations with Brussels and Berlin. This is served by the non-economic proposals contained in Wen Jiabao's speech in Warsaw during the inauguration of the $16+1$ format and the effects of their implementation. Of the 12 steps towards friendly cooperation with Central and Eastern Europe, the last five concerned non-economic cooperation:

1. Propose to hold a forum on cultural cooperation between China and central and eastern European countries in 2013 in China and, in this context, hold regular high-level and expert meetings on culture, cultural festivals and theme activities.

2. Provide 5,000 scholarships to the 16 central and eastern European countries in the next five years. Support the Confucius Institutes and 
Confucius Classrooms program in the 16 countries and invite 1,000 students from relevant countries to study the Chinese language in China in the next five years. Enhance inter-university exchanges and joint academic research, and send 1,000 students and scholars to the 16 countries in the next five years. The Ministry of Education of China plans to host an education policy dialogue with central and eastern European countries next year.

3. Propose to establish a tourism promotion alliance between China and central and eastern European countries, which will be coordinated by China Tourism Administration and open to participation by civil aviation authorities, travel agencies and airline companies of the two sides. The purpose is to enhance mutual business promotion and joint tourist destination development, and explore the possibility of opening more direct flights between China and the 16 central and eastern European countries. China Tourism Administration plans to co-organize a tourism products promotion for China and central and eastern European countries during the China International Tourism Mart to be held in Shanghai this autumn.

4. Establish a research fund on relations between China and central and eastern European countries. China is ready to provide RMB2 million yuan every year to support academic exchanges between research institutes and scholars of the two sides.

5. China plans to host the first young political leaders forum of China and central and eastern European countries in 2013 and invite youth representatives from both sides to the forum to enhance mutual understanding and friendship (Ministry of Foreign Affairs of the People's Republic of China, 2012).

All these steps have been largely implemented, primarily in the field of educational cooperation, including scholarships (including for learning Chinese) for students from Central and Eastern Europe. The evaluation of the $16+1(17+1)$ format in the non-economic sphere indicates its effective use as a soft power tool. 


\section{An attempt at a forecast}

An attempt to make a forecast using the extrapolation method of the current trends in the further direction of Chinese economic expansion in Central and Eastern Europe leads to a several conclusions. Further tightening of China's cooperation with Germany and France is expected, as indicated by the investment agreement with China concluded by the European Union on December 30,2020, which was one of the priorities of German policy. Further development of German-Russian cooperation is also very likely, an example of which is Nord Stream 2 and the Sino-Russian one in connection with the expansion of the New Silk Road. Therefore, it is very unlikely that Chinese infrastructure investments in Central and Eastern European countries will increase to a degree that could affect their economic development. This situation could even worsen if the United States withdraws from Europe.

ADAM KUŹ, MA

Faculty of Political Sciences and Administration

Kazimierz Wielki University in Bydgoszcz

Jana Karola Chodkiewicza 30, 85-064 Bydgoszcz

adam-kuz@wp.pl

\section{Bibliography}

Avitrader (2005). Airbus sells 150 A320 family aircraft to China. Retrieved from: https:// www.avitrader.com/2005/12/05/airbus-sells-150-a320-family-aircraft-to-china/.

Banasiak, C. (2015). Chińskie déjà vu. Retrieved from: http://www.pgt.pl/chinskie-deja-vu.

Chazan, G. (2016). German angst over Chinese MઐA. Retrieved from: https://www. ft.com/content/e0897e24-598e-11e6-8d05-4eaa66292c32.

China Africa Research Initiative (2019). Chinese loans do Africa. Retrieved from: http:// www.sais-cari.org/research-chinese-loans-to-africa.

The Congressional Research Service (2020). China's Engagement with Latin America and the Caribbean. Retrieved from: https://crsreports.congress.gov/product/pdf/ IF/IF10982.

European Commission (2019). EU-China-A strategic outlook. Retrieved from: https:// ec.europa.eu/commission/sites/beta-political/files/communication-eu-china-a-strategic-outlook.pdf. 
Fornes, G., Mendes, A. (2018), The China-Latin America Axis: Emerging Markets and their Role in an Increasingly Globalized World. Basingstoke: Palgrave Macmillan.

Frankfurter Allgemeine Zeitung (2019). China verfolgt eigene Interessen global beinhart. Retrieved from: https://www.faz.net/aktuell/wirtschaft/mehr-wirtschaft/neue-seidenstrasse-maas-warnt-italien- -wegen-obor-16105324.html.

Gaspers, J. (2016). Germany Wants Europe to Help Shape China's Belt and Road Initiative. Retrieved from: https:/thediplomat.com/2016/12/germany-wants -europe-to-help-shape-chinas-belt-and-road-initiative/.

Gruszczyński, B. (2016). Chinese multilateralism. Comparative study of Chinese cooperation with Africa and Central and Eastern Europe. Lodz: University of Lodz.

Halecki, O. (1944). The Historical Role of Central-Eastern Europe. Annals of the American Academy of Political and Social Science, 14.

Hutt, D. (2020). Prospects for China money in central and eastern Europe chill. Retrieved from: https://asia.nikkei.com/Politics/International-relations/Prospects -for-China-money-in-central-and-eastern-Europe-chill.

Koutantou, A., Goh, B. (2016). After Piraeus Port, China's COSCO eyes Greek trains to build Europe hub - sources. Retrieved from: http://www.reuters.com/article/ greece-china-port-idUSL8N14X17R.

KPMG International (2010). World class aspirations: The perceptions and the reality of China outbound investment. Retrieved from: https://assets.kpmg/content/dam/ kpmg/pdf/2010/10/china-outbound-investment-201010.pdf.

Kratz, A., Huotari, M., Hanemann, T., Arcesati, R. (2019). Chinese FDI in Europe. Retrieved from: https://merics.org/en/report/chinese-fdi-europe-2019-update.

Lubina, M. (2019). Pokraczne wejście smoka. Chiny i format 1+16/17. Retrieved from: https://usa-ue.pl/teksty-i-komentarze/teksty/pokraczne-wejscie-smoka -chiny-i-format-116-17/.

Mackinder, H. (1942). Democratic Ideals and Reality: A Study in the Politics of Reconstruction. London: Constable Publishers.

Magocsi, P.R. (2005). Eastern, East-Central, or Central Europe: Where is it and What is it? Pittsburgh, PA: National Slovak Society, pp. 128-140.

Matura, T. (2012), The Pattern of Chinese Investments in Central Europe. Retrieved from: https://www.academia.edu/2641945/The_Pattern_of_Chinese_Investments _in_Central_Europe.

Ministry of Foreign Affairs of the People's Republic of China (2012). China's Twelve Measures for Promoting Friendly Cooperation with Central and Eastern European Countries. Retrieved from: https://www.fmprc.gov.cn/mfa_eng/topics_665678/ wjbispg_665714/t928567.shtml.

Marszałek-Kawa, J., Dmochowski, T. (red.). (2018). Rozważania o kierunkach współczesnej polityki Chin. Toruń: Wydawnictwo Adam Marszałek.

Mission of the People's Republic of China to the European Union (2013). China's policy paper on EU. Retrieved from: http://www.chinamission.be/eng/zywj/zywd/ t1227623.htm.

Oficjalna strona Prezydenta Rzeczypospolitej Polskiej (1997). Wizyta oficjalna w Chinach - Komunikat. Retrieved from: https://www.prezydent.pl/aleksandra-kwasniew- 
skiego/aktualnosci/rok-2000-i-starsze/art,158,220,wizyta-oficjalna-w-chinach-komunikat.html.

Olechowski, A. (2020). Editorial. Polish Political Science Yearbook, 49(3), 5-6.

Pabisiak, J. (2020). Dangerous, Yet Not So Unique. Characteristics of the Chinese Social Credit System. Polish Political Science Yearbook, 49(3), 30-53.

Poggetti, L. (2017). One China - One Europe? German Foreign Minister's Remarks Irk Beijing. Retrieved from: https://thediplomat.com/2017/09/one-china-oneeurope-german-foreign-ministers-remarks-irk-beijing/.

Polska Agencja Inwestycji i Handlu S.A. (2014). Inauguracja Sekretariatu 16+1 $w$ Warszawie. Retrieved from: ttps://www.paih.gov.pl/20141119/inauguracja _sekretariatu_w_warszawie.

Rudnicka, J. (2020). Import nach Deutschland aus ausgewählten Ländern bis 2019. Retrieved from: https://de.statista.com/statistik/daten/studie/152111/umfrage/ import-nach-deutschland-aus-ausgewaehltenlaendern.

Stokes, J. (2015). China’s Road Rules. Foreign Affairs, 19.

Sullivan, M.P. (2020). China's Engagement with Latin America and the Caribbean. Retrieved from: https://crsreports.congress.gov/product/pdf/IF/IF10982.

Turcsányi, R., Qiaoan, Runya, (2020). Friends or foes? How diverging views of communist past undermine the China-CEE ' $16+1$ platform'. Asia Europe Journal, 18, 397-412.

Turcsányi, R., Matura T., Fürst R. (2014). The Visegrad countries' Political Relations with China: Goals, results and prospect. Retrieved from: https://www.researchgate.net/ publication/274834960_The_Visegrad_Countries\%27_Political_Relations_with_ China. 